\title{
Less Is More: A Cross-Generational Analysis of the Nature and Role of Racial Attitudes in the Twenty-First Century
}

\author{
Christopher D. DeSante, Indiana University \\ Candis Watts Smith, Pennsylvania State University
}

\begin{abstract}
After landmark Civil Rights legislation was implemented, scholars provided evidence that the nature and structure of whites' racial attitudes changed from the Jim Crow era. They devised survey questions to capture newer, more acceptable forms of racial animus. One scale that came out of this effort and that receives the most empirical attention today is the racial resentment scale. Given the vast changes the American racial landscape has undergone since that scale was originally developed, we question whether this set of measures is related to racial attitudes in the same way across generational cohorts. We show two key findings: younger whites are not bringing about any meaningful change in the aggregate levels of racial resentment. Second, and more importantly, we show that while younger whites appear to have lower levels of racial resentment, these survey items are more strongly related to old-fashioned antiblack affect among younger whites. Thus, when it comes to millennials' racial attitudes, "less is more."
\end{abstract}

W ill racism end when old bigots die?" That was a question posed by National Public Radio's Code Switch in early 2017, just a few weeks before Donald Trump was inaugurated. In the first year of his term, America has witnessed a groundswell of overtly racist behavior. This was perhaps most starkly demonstrated by the August 2017 Unite the Right rally in Charlottesville, Virginia, which ended with over 30 people injured and one young woman, Heather Heyer, killed when a driver intentionally ran over the counterprotestors. When Trump initially commented on these events, he failed to explicitly denounce the white nationalists and shifted blame to the counterprotestors, saying there was "hatred, bigotry, and violence on many sides." Perhaps one looks at Trump, a white man in his early seventies, and attributes his comments to the thinking of a bygone era, an older generation whose beliefs are not long for this world. After all, if older whites are the ones who are the most prejudiced, we may hope that newer generations could turn the tide of racial attitudes in the United States. In this article we demonstrate, in several different ways, that this simply is not the case. Younger whites, those who are part of the millennial generation, may appear to have lower levels of racial prejudice, but these attitudes are more strongly linked to old-fashioned racial stereotypes than for older whites. ${ }^{1}$ In this sense, less is more; while the average level of racial resentment is lower among millennials, racial resentment has a more virulent effect for this group in comparison to their predecessors. Racially resentful millennials rely on old-fashioned stereotypes, adopt notions of "reverse discrimination," and are much less like likely to support policies that aim to produce greater racial equity than are older, prejudiced whites.

This article proceeds in five parts. First, we briefly discuss the modern "postracial" America narrative and summarize how social scientists have measured racial attitudes in the

Christopher D. DeSante (cdesante@indiana.edu) is an assistant professor of political science at Indiana University, Bloomington, IN 47405. Candis Watts Smith (cwsmith@psu.edu) is an associate professor of political science and African American studies at Pennsylvania State University, University Park, PA 16802.

Data and supporting materials necessary to reproduce the numerical results in the article are available in the JOP Dataverse (https://dataverse .harvard.edu/dataverse/jop). An online appendix with supplementary material is available at https://doi.org/10.1086/707490.

1. According to Pew Research, the millennial Generation is composed of Americans born between 1981 and 1996. These cutoffs are neither arbitrary nor set in stone; as such, we include those born between 1980 and 1998 in our analysis. We use the phrases "young whites," "younger whites," and "millennials" interchangeably, and we only analyze non-Hispanic white Americans.

The Journal of Politics, volume 82, number 3. Published online May 28, 2020. https://doi.org/10.1086/707490 (c) 2020 by the Southern Political Science Association. All rights reserved. 0022-3816/2020/8203-0011 $\$ 10.00$ 
mass public. Next, we explain why we believe younger whites may have a systematically different orientation toward the measures of racial attitudes that social scientists rely on most. Third, we assess the extent to which aggregate levels in racial resentment over the past 30 years have been changed due to cohort replacement. The analysis that we use here will also allow us to determine whether the millennial generation is unique in their levels of racial animus, aside from the fact that they are still relatively young. ${ }^{2}$ Fourth, we examine whether racial resentment operates identically across this generational divide; here our goal is to ascertain whether the effect of racial animus has a particularly pernicious effect on one generational cohort rather than another. Finally, we conclude that, without properly correcting for how these measures operate across generations, scholars may prematurely conclude that younger whites are less racially prejudiced, and we discuss the implications of these findings.

\section{RACIAL ATTITUDES IN THE POST-OBAMA ERA}

It is not uncommon for scholars, pundits, and major polling outfits to suggest that the United States maintains its steady march toward racial egalitarianism in large part due to cohort replacement and millennials in particular (Hochschild, Weaver, and Burch 2012; Page and Ung 2016; Pew Research Center 2010). For example, journalist Tim Rutten summarized this phenomenon, explaining generational differences with regard to thinking about race: "[President Obama] personifies and articulates the postracial America in which most of our young people live... skin color is no longer a physical marker for most of them. By and large, our sons and daughters describe their friends as tall or short, funny or serious, as good students or poor athletes, but seldom - as earlier generations would have done - as a 'black guy' or a 'white girl'” (2008). Even the Pew Research Center (2010) has asserted that the millennial generation is the most racially tolerant generation in history, citing survey data that show members of the millennial generation are more likely than older Americans to approve of interracial marriage and interracial dating.

These findings fit a postracial narrative - that race and racism are no longer important in America, but we take those findings as evidence that many have a myopic, if not fundamental misunderstanding of how race and racism function in the United States, rather than as a signal that whites' attitudes have profoundly changed. First, those explanations focus mainly on attitudinal survey items and ignore institutional and structural inequalities (Bonilla-Silva

2. People tend to be more liberal when they are young but may become more conservative as they age; the methodological strategy we employ here will allow us to parse out life cycle effects from cohort effects.
1997). Second, both polling centers and the media rely on relatively antiquated measures of racial prejudice. Commonly, these items tap into old-fashioned racism-asking about social distance or stereotypes-questions that are either prone to social desirability bias or no longer controversial. For example, most Americans approve of interracial contact and disdain racial discrimination or are unwilling to publicly admit otherwise (Schuman et al. 1997). As others have argued previously, since we know that expressions of racial animus have evolved over time, our measures of racial attitudes must change (Bonilla-Silva 2017; Henry and Sears 2002; Schuman et al. 1997).

There was a significant decline in biological racism between the 1940s and 1970s, but by the late 1970s and early 1980s, scholars noticed that even though an increasing proportion of white Americans supported formal principles of (racial) equality, their support for implementing public policies aimed at ameliorating racial inequality was lackluster; researchers also noted that the implementation of these policies seemed to stimulate new configurations of racial attitudes (Schuman et al. 1997; Sears et al. 2000). In that context, scholars embarked on a conceptual enterprise to determine whether the existing measures of racial attitudes (e.g., social distance, biological racism) were still relevant and useful in measuring whites' racial attitudes or predicting political attitudes and behaviors. Social psychological research suggested that a more subtle and covert form of racism had developed among the American population, and scholars developed new theories and measures for these evolved attitudes, such as aversive racism (Dovidio 2001), symbolic racism (Kinder and Sears 1981), racial resentment (Kinder and Sanders 1996), laissez-faire racism (Bobo, Kluegel, and Smith 1997), modern racism (McConohay 1986), and subtle racism (Pettigrew and Meertens 1995) to name a few. Each was developed to more accurately describe new forms of racial attitudes and more socially acceptable expressions of prejudice.

Racial resentment, in particular, has garnered substantial attention in political science. Scholars noted that prior to the Civil Rights Movement, the "race problem" in America was marked by unequal opportunity, discrimination, and lack of enforcement of constitutional rights. After the late 1960s, the race problem centered on the threat that blacks posed to the social order. More specifically, Kinder and Sanders (1996) explain that after the Watts riots, and others like it, whites were increasingly likely to suggest that blacks lagged behind whites on important socioeconomic indicators because of their failure to live up to core American values. This reinterpretation of the American race problem is the foundation of racial resentment; as Kinder and Sears 
explain, their measure is "a blend of affect and the kind of traditional American values embodied in the Protestant Ethic. [This attitude] represents a form of resistance to change in the racial status quo based on moral feelings that blacks violate such traditional American values as individualism and self-reliance, the work ethic, obedience, and discipline" (1981, 416).

It is important for our purposes to note that the validity of racial resentment appears to have stood the test of time; a number of studies have shown that racial resentment influences whites' attitudes on the death penalty (Unnever and Cullen 2007), social welfare policies (Kinder and Mendelberg 2000), affirmative action (Bobo 2000), vote choice (Kinder and Sears 1981; Tesler and Sears 2010), who is deserving of governmental help (DeSante 2013), and much more.

There are, however, critics of this measure (Kluegel and Bobo 1993; Sniderman, Crosby, and Howell 2000; Sniderman and Piazza 1993; Sniderman and Tetlock 1986; Stoker 1998; Wilson and Davis 2011), who argue that the measure is tapping conservative values more than racial animus. While there have been a number of recent works (Lewis-Beck, Tien, and Nadeau 2010; Piston 2010; Tesler 2012, 2013, 2016; Valentino and Brader 2011) that show how racial resentment still relates to prejudicial attitudes in contemporary America, some still have problems with the measure, arguing that it is correlated with conservative ideology (Carmines, Sniderman, and Easter 2011; Sears, Sidanius, and Bobo 2000).

We do have a concern with the racial resentment scale, but we depart from that debate in important ways. Our concern focuses on temporal context. Concepts like symbolic racism and racial resentment are based in the broader theory of symbolic politics, a theory that "holds that much adult political behavior results from symbolic predispositions acquired before full adulthood ... and as reflecting the norms dominating the young individual's informational environment" (Sears 1988); in other words, racial attitudes form "through a process of classical conditioning," or socialization (Sears 1993, 120). Given that generational cohorts are socialized in specific eras, have particular experiences, and are likely to uphold the social norms of their day (Mannheim 1952), we are concerned with the extent to which these "new" measures remain relevant to, and accurately describe, the attitudes of younger white Americans. What is more, given that expressions of racial attitudes change in response to major political, social, and economic transformations in society, we question whether the measures that were developed in a particular historical context map onto today's contemporary, dominant racial ideology.

Members of the millennial generation have lived the entirety of their lives in an America where de jure segregation is illegal, diversity is celebrated, minority political representation is unremarkable, and for whom skin color ostensibly no longer serves as a "physical marker." This group has been socialized in a different racial milieu, one marked by colorblind racial ideology (Apfelbaum, Sommers, and Norton 2008; Bonilla-Silva 2014; Jackson 2008). As such, we question whether the scale that political scientists rely on most to assess racial attitudes is related to millennials' political attitudes, behaviors, and policy preferences in the same way as it for their predecessors.

\section{WHAT MAKES MILLENNIALS DIFFERENT?}

Considering how America's racial landscape and social norms have changed since the development of the racial resentment battery, it may be the case that the racial resentment scale is not necessarily capturing racial attitudes identically across generational cohorts. If the narrative which suggests that the United States is still on its steady march toward racial equality is correct, we would expect that the most recent cohorts of whites would exhibit lower levels of racial resentment than their predecessors. However, we suspect that there is a different possibility altogether. Given that younger whites have been socialized to avoid talking about race or revealing racially prejudiced opinions, the survey items we use might be operating differently across these groups. We believe this is worthy of examination for the simple fact that younger whites have a different lived sociohistorical experience, an experience that differs in critical ways from the era that initially inspired scholars to develop the racial resentment scale. Our theory is that younger whites have life experiences that are unique, in two important ways, which differentiate them from previous generations; these differences will influence the relationship and effect that their racial attitudes have on the political attitudes, behaviors, and policy preferences.

First, there is what we call a "historical difference." We rely on a similar logic that undergirds the first wave of "new racism" work: as America faces new social, political, and economic challenges, socially acceptable expressions of prejudice evolve. The racial resentment battery was created at a particular historical moment, one that may be less salient to whites of a certain age. For example, one survey item asks how strongly a respondent agrees with the statement, "Irish, Italians, Jews and other minorities overcame prejudice and worked their way up. Blacks should do the same without any special favors." For members of the silent generation (those born between 1925 and 1945) or the baby boomers (1946-64), the narrative of these specific immigrant groups might be more salient, if only due to the raw number of immigrants coming to America from, for example, Italy and Ireland. While those were some of the largest immigrant groups in the first 
half of the twentieth century, those numbers dropped, while African and Asian immigration grew exponentially in the second half of the century. ${ }^{3}$

Additionally, one of the questions asked is, "it's really a matter of some people not trying hard enough; if blacks would only try harder, they could be just as well off as whites." Some scholars have pointed out that this is not a helpful question because it is double barreled, asking respondents two questions at once. However, others have argued that tying these two ideas together was a deliberate part of the Republican Party's Southern strategy, thus creating a well-formed question. ${ }^{4}$ This logic is not one that members of the millennial generation are likely to be familiar with, and they may instead be focused on the double-barreled aspect of the question.

In addition to the fact that these survey items reference specific historical events and racialized policies that lay outside of white millennials' memory or knowledge (Dillon 2011), it is important to note that asking about race, and about "blacks" specifically, raises social desirability red flags for younger respondents in a way that they do not for older Americans. When the racial resentment scale was developed "compared with most efforts to measure racial animosity, these questions ... [appeared] rather subtle" (Kinder and Sanders 1996, 106), but considering today's environment, these questions may miss the mark, as the mere mention of race is unacceptable, especially for younger Americans. Anecdotally, after the 2014 midterm election, voters were reportedly taken aback by the questions that compose the racial resentment battery; some felt that the mere asking of the questions implied that the interviewees were racists (Ries 2014).

The second, related difference, which we call the "psychosocial difference," concerns how millennials have been socialized. As mentioned, the dominant racial ideology in the United States shifted from Jim Crow to covert or symbolic racism, largely measured by the racial resentment scale. An emerging consensus among critical race scholars, sociologists, and psychologists is that "color-blindness" is currently the basis for contemporary American racial ideology and

3. Between 1900 and 1949 , the United States granted permanent residence status to over 3.8 million Italians and over 750,000 Irish. From 1950 until 2000, those numbers drastically declined to about 671,000 and 184,000 , respectively. Over those same periods, the number of African immigrants increased nearly twentyfold, from 31,000 to nearly 600,000 , and the number granted permanent resident status coming from Asia increased from 750,000 during 1900-1949 to approximately 7.1 million in the second half of the previous century. These statistics come from the Census Bureau's (2001) "Profile of the Foreign-Born Population in the United States: 2000," table 3-1.

4. We would like to thank one of our anonymous reviewers for pointing this out to us. characterizes the environment in which young whites have been socialized (Apfelbaum, Sommers, and Norton 2008; Bonilla-Silva 2014; Bonilla-Silva and Lewis 1999; BonillaSilva, Lewis, and Embrick 2004; Carr 1997; Forman 2006; Jackson 2008; Lewis 2001; Mueller 2017). Frankenberg explains that a color-blind perspective is a "mode of thinking about race organized around an effort not to 'see' or at any rate not to acknowledge race differences," as this is the "'polite" language of race" $(1993,142)$.

Bonilla-Silva and Lewis $(1999,56)$ outline the elements that make up a color-blind racial structure; they are "(1) the increasingly covert nature of racial discourse and practices; (2) the avoidance of racial terminology and the ever growing claim by whites that they experience 'reverse racism'; (3) the elaboration of a racial agenda over political matters that eschews direct racial references; (4) the invisibility of most mechanisms that reproduce racial inequality; and finally, (5) the rearticulation of a number of racial practices characteristic of the Jim Crow period of race relations."

Furthermore, this shift is largely marked by an increasing desire for political correctness and avoidance of race (Jackson 2008). The avoidance of discussing race largely stems from the perception that talking about race these days is "fraught with the risks of misunderstanding and social sanction"; the social norms of contemporary society guide whites' motivation to "avoid the appearance of prejudice" (Apfelbaum, Sommers, and Norton 2008, 918).

Psychologists have also recorded this tendency to avoid talking about or even mentioning race. For example, Apfelbaum and his colleagues (Apfelbaum, Pauker, et al. 2008; Apfelbaum, Sommers, and Norton 2008) show that whites adopt "strategic color-blindness," or an effort to completely avoid mentioning race even in a task where pointing out someone's race is actually helpful. They also found that younger children (age 8-9 years) are able to outperform older children in a basic categorization task, where acknowledgement of race facilitates performance. Their research reveals that children as young as 10 years old recognize the potential social sanction of mentioning race and avoid doing so even at the expense of successfully completing a task. These scholars suggest that we may be seeing a "critical transition in human social development" around the issues of race and racism (Apfelbaum, Pauker, et al. 2008, 1513).

Scott Blinder has developed a theory of "two-tracked socialization," which explains what we are likely to see empirically among young people in this era of color-blindness (Blinder 2007). Blinder shows that since young whites have been socialized to avoid directly addressing issues of race and racism, they are likely to experience cognitive dissonance when trying to explain racial inequalities, simply because 
they do not have the language. As such, we may see that young people are likely to be incredibly supportive of symbols that demonstrate that they are antiracist, but it may also mean that they are less likely to pursue policies that ameliorate racial disparities because they do not have a firm grasp on the role of institutional, systemic, and structural factors that lead to racial disparities. Indeed, because they have to cobble together explanations for ongoing inequality, they may latch onto old-fashioned stereotypes, rely on explanations of "behavior," "culture," or "class," grasp onto notions of "reverse discrimination," or be racially apathetic altogether (Dietrich 2015; Forman 2006; Hagerman 2018).

We take all of this to mean that any expression of racial animus is more costly for the youngest members of the population. In other words, it might take a higher level of racial animus for younger whites to agree with the items of the racial resentment scale. In sum, the measures of racial attitudes that political scientists use may fail to capture the sentiments that arise from being socialized in an era of colorblindness, or we may simply be missing important nuances by not keeping tabs on the different relationship that existing measures may have with new ways of thinking and talking about race across generational cohorts.

These generational differences present us with an interesting opportunity to test two key hypotheses. The first hypothesis concerns whether changes in aggregate levels of racial resentment can be attributed to less racially prejudiced whites entering the population. ${ }^{5}$ We predict that young whites will report lower levels of racial animus (due to the era in which they have been socialized), thus reducing aggregate levels of racial animus as new cohorts are introduced into national samples.

The second hypothesis stems from the psychosocial generational differences. We hypothesize that although young whites, on average, will report lower racial resentment scores compared to older whites, the effect of racial resentment will be particularly pernicious and may be more strongly related to old-fashioned prejudice. We assert that it is more difficult, psychologically, for younger whites to signal racial prejudice. In turn, when they do signal racial prejudice, it should have a greater effect on related political attitudes.

5. In previous versions we used the term "racial liberals" and recognize this phrasing has become common. While some may believe that the racially conservative/liberal distinction is helpful because it blurs the lines between the two concepts that compose racial resentment (racism and political ideology), we do not. Given the findings of this article, it is clear that younger whites who are less racially resentful ("racially liberal") are actually less prejudiced and that those who are more resentful ("racially conservative") are significantly more prejudiced. At the end of the day we are more interested in the racist attitudes held by whites, not whether they are racially liberal or conservative.

\section{TRENDS IN RACIAL RESENTMENT}

Aggregate changes in racial attitudes can stem from several mechanisms. Yang et al. $(2008,1698)$ explain that "period and cohort effects reflect the influences of social forces." Period variations often result from shifts in social, historical, and cultural environment. Cohort variations are conceived as the essence of social change and may reflect the effects of early life exposure to socioeconomic, behavioral, and environmental factors that act persistently over time to produce differences in life course outcomes for specific cohorts." Finally, scholars show that some aggregate changes in racial attitudes can stem from age effects, which are changes in a person's attitudes as they move through the life cycle. We expect that older whites, ceteris paribus, would exhibit higher levels of racial resentment; people may become more racially resentful as they age. A postracial, or steady march, narrative of American society leads us to expect a monotonic decline in racial resentment over time, and further, we expect younger generational cohorts to be at the forefront of aggregate change.

Table 1 presents the average score on the four-item racial resentment battery whenever all four questions were asked on the American National Election Study (ANES). Respondents were asked the following: (1) Irish, Italian, Jewish, and many other minorities overcame prejudice and worked their way up. Blacks should do the same without any special favors. (2) Generations of slavery and discrimination have created conditions that make it difficult for blacks to work their way out of the lower class. (3) Over the past few years, blacks have gotten less than they deserve. (4) It's really a matter of some people not trying hard enough; if blacks would only try harder, they could be just as well off as whites. The responses for questions 1 and 3 are reversed before all responses are added into a scale. The overall racial resentment scores have been recoded to run from 0 to 1 , with higher scores indicating higher levels of racial resentment. ${ }^{6}$

As we can see, these means are remarkably stable: ranging from a high of 0.64 (multiple years) to a low of 0.57 in 2016, not necessarily moving in a monotonic direction. As the ANES only interviews adults age 18 or older, the first millennial would have entered the survey in 1998; as such the proportion of respondents who are millennials increased from just $1 \%$ in the 1998 wave to over $25 \%$ in 2016.

In order to parse out the extent to which the change- or the lack thereof - in racial attitudes over time is due to cohort replacement, a primary mechanism of social change, rather than period effects or age effects we use a methodological

6. Over the course of time that the ANES has been around, the survey has been administered both face-to-face, as well as remotely. For comparability we use only face-to-face interviews. 
Table 1. Whites' Levels of Racial Resentment, 1986-2016

\begin{tabular}{cc}
\hline Year & Mean \\
\hline & \\
1986 & .60 \\
1988 & .64 \\
1990 & .58 \\
1992 & .62 \\
1994 & .65 \\
2000 & .64 \\
2004 & .64 \\
2008 & .65 \\
2012 & .64 \\
2016 & .57 \\
\hline
\end{tabular}

tool called the "intrinsic estimator" designed for age-periodcohort (APC) analysis. This estimation technique enables us to control for age, period, and cohort effects simultaneously, thus allowing us to assess the role that various generational/ birth cohorts play in maintaining, exacerbating, or ameliorating racial animus in the United States.

Until relatively recently, research that centers on cohort replacement has traditionally been unable to disentangle cohort effects from period and age effects (Dowden and Robinson 1993; Hochschild et al. 2012; Steeh and Schuman 1992). Similarly, those works that focus on macrochanges across time fail to discern period effects from cohort and age effects (Hunt 2007; Kluegel 1990; Schuman et al. 1997) as it has been difficult for researchers to disentangle each from the others. ${ }^{7}$ We estimate APC effects with intrinsic estimator models (Yang, Fu, and Land 2004; Yang and Land 2013; Yang et al. 2008) as this statistical method overcomes the identification problem of APC models, which typically employ nonarbitrary constraints.

Not only did previous methods require researchers to make strong assumptions about the data a priori, the resulting statistical estimates were sensitive to these choices (Yang et al. 2004). In contrast, the intrinsic estimator does not depend on arbitrary adjacency constraints and yields robust estimates of trends by age, period, and cohort. While this method is relatively new, it has been used by political scientists to explain changes in voting behavior (Stegmueller 2014), the effects of political socialization (Neundorf and Niemi 2014), and changes in blacks' explanations of racial

7. "Age, period, and cohort measures cannot simultaneously be included in a standard regression model due to linear dependency," and it should be duly noted that analysis of "cohort effects are unreliable without including age in the model" (Schwadel and Stout 2012, 238). disparities (Smith 2014). To the best of our knowledge, this is the first article to apply the method to examine changes in whites' racial attitudes.

For this estimation procedure, our data come from the 1986-2016 ANES data sets, with a total of 10,314 face-to-face respondents who identified as white and answered all four racial resentment items. As we show in table 1, the commonly used racial resentment scale (the sum of the four items, ranging from 0 to 1 ) has hardly changed at the aggregate level over the last 30 years. Because we are interested in the crossgenerational change and explanatory power of the racial resentment scale, we use the intrinsic estimator procedure to model racial resentment; following standard practices, ages, periods, and cohorts are grouped into five-year categories. ${ }^{8}$ Consequently, we estimate coefficients for six periods, 14 age groups, and 19 cohorts; these are presented in table 2.

While the model estimates are presented in table 2, we believe that the model estimates are much easier to interpret graphically, and we illustrate the effects for the age, period, and cohort coefficients in figure 1 . The dashed line approximates the average level of racial resentment across all age, periods, and cohorts. Deviations away from the dashed line, plotted as point estimates and their corresponding 95\% confidence intervals, provide evidence that a particular age group, period, or cohort are substantively different from the overall mean. Those coefficients that were marked as statistically significant in table 2 are those where the confidence interval does not contain the overall mean.

As the upper left panel in figure 1 shows, age is strongly related to feelings of racial resentment, as many might expect. Independent of the period the survey was conducted as well as the birth cohort of a respondent, whites tend to become marginally more racially resentful as they enter their late forties and early fifties, a trend that continues for most of their lives. Our results show that when white Americans are age 30 years or less (even controlling for what year the survey was taken and what year the respondents are born), they tend to express less racial resentment than they do as they age. Again, we tend to expect people to become more conservative (on a variety of issues) as they age, and the results here provide some support for that, although the differences (which are statistically different from zero) are not as large as some scholars may expect. The largest difference between any two age groups is about 0.04 on the one-point scale, only $4 \%$ of the total possible change.

The upper right panel in figure 1 depicts the estimated period effects. These data serve as evidence that racial

8. This is the traditional method for demographers and for the APCIE method; for more details, see Yang et al. (2008). 
Table 2. Age, Period, and Cohort Estimates Predicting Racial Resentment (APC-IE)

\begin{tabular}{|c|c|c|}
\hline & Coefficient & SE \\
\hline \multicolumn{3}{|l|}{ Age group: } \\
\hline $18-24$ & $-.036^{\star}$ & .009 \\
\hline $25-29$ & $-.024^{*}$ & .008 \\
\hline $30-34$ & -.006 & .008 \\
\hline $35-39$ & -.004 & .008 \\
\hline $40-44$ & $-.032^{\star}$ & .008 \\
\hline $45-49$ & -.007 & .009 \\
\hline $50-54$ & .011 & .009 \\
\hline $55-59$ & $.024^{*}$ & .009 \\
\hline $60-64$ & $.029^{*}$ & .009 \\
\hline $65-69$ & $.026^{*}$ & .010 \\
\hline $70-74$ & $.017^{\star *}$ & .011 \\
\hline $75-89$ & -.002 & .011 \\
\hline $80-84$ & .006 & .014 \\
\hline \multicolumn{3}{|l|}{ Survey period: } \\
\hline 1985-89 & $-.014^{*}$ & .005 \\
\hline 1990-94 & -.002 & .005 \\
\hline $2000-2004$ & .003 & .006 \\
\hline $2005-9$ & .003 & .008 \\
\hline $2006-10$ & $.021^{*}$ & .007 \\
\hline 2011-16 & $-.012^{\star}$ & .006 \\
\hline \multicolumn{3}{|c|}{ Cohort birth years: } \\
\hline 1910-14 & $.047^{\star *}$ & .028 \\
\hline $1915-19$ & .015 & .016 \\
\hline $1920-24$ & .019 & .014 \\
\hline $1925-29$ & -.003 & .013 \\
\hline $1930-34$ & -.006 & .011 \\
\hline $1935-39$ & .004 & .011 \\
\hline $1940-44$ & -.008 & .011 \\
\hline $1945-49$ & $-.018^{\star \star}$ & .010 \\
\hline $1950-54$ & $-.018^{\star}$ & .009 \\
\hline $1955-59$ & $-.021^{\star}$ & .009 \\
\hline $1960-64$ & -.008 & .008 \\
\hline $1965-69$ & .012 & .008 \\
\hline $1970-74$ & $.027^{\star}$ & .008 \\
\hline $1975-79$ & $.026^{*}$ & .010 \\
\hline $1980-84$ & $-.031^{\star}$ & .012 \\
\hline $1985-89$ & -.019 & .014 \\
\hline 1990-94 & .003 & .016 \\
\hline 1995-98 & -.022 & .021 \\
\hline Constant & $.631^{\star}$ & .004 \\
\hline
\end{tabular}

Source. 1986-2016 American National Election Studies.

Note. Estimates and standard errors calculated by the APCIE estimation procedure in Stata 13. $N=10,209$. Non-Hispanic white, face-to-face respondents only.

${ }^{*} p<.05$, two-tailed test.

${ }^{* *} p<.05$, one-tailed test. resentment has been significantly increasing among whites across time, a finding that runs counter to the popular narrative that racial progress is inevitable. Racial resentment among whites has significantly increased over the past three decades. Scholarship on the 2008, 2012, and 2016 presidential elections suggested that we should have expected this trend (Lewis-Beck et al. 2010; Piston 2010; Tesler 2012, 2013, 2016; Valentino and Brader 2011), but here we can precisely estimate just how great an effect these periods had compared to other mechanisms of social change. Overall, we see an uptick over time, and even the downward movement in the last period puts us back closer to the first, 1986-90.

The bottom panel in figure 1 allows us to speak to our hypothesis concerning whether newer cohorts report lower levels of racial animus; again, what the APC-IE analysis does is allows us to ascertain whether cohorts are different from one another, controlling for when respondents are asked the questions or how old they are when they are asked.

Moving from left to right, our data reveal that older birth cohorts - those born in the early twentieth century - exhibit higher levels of racial resentment than those born in the midtwentieth century. It also shows that cohorts that make up the boomer generation, those born from 1946 to 1964 and socialized during the Civil Rights Era, appear to have lower levels of racial resentment than their predecessors. Then we see a slight uptick in racial resentment among those born in the 1970s, a group that other research has shown is not particularly racially progressive (Kluegel 1990), and they show that cohort replacement produces a potential for attitudinal change but not a guarantee of racial progress.

Finally, on the right, figure 1 reveals that beginning with those born in 1980, the level of racial resentment seems to monotonically decrease, and all but one of those coefficients is statistically significant at the .05 level. Substantively, this means that whites born between 1980 and 1998 report lower levels of racial resentment than those born prior to 1980 , and some millennials (e.g., those born in the early '90s) appear to be less racially resentful than their predecessors, although not by much.

We have little evidence for the conjecture that the United States has experienced a steady decline in racial resentment over time, but we do have some, albeit weak, evidence that young generational cohorts have lower levels of racial animus. Our analysis allows us to assert that it is not because millennials are young (although the eldest are nearly 40 years) or that they are simply liberal but instead that millennials are distinct from their predecessors. In all, millennial whites generally harbor lower levels of racial resentment than their predecessors, but our next step is to determine whether racial resentment among millennials is also further removed from 

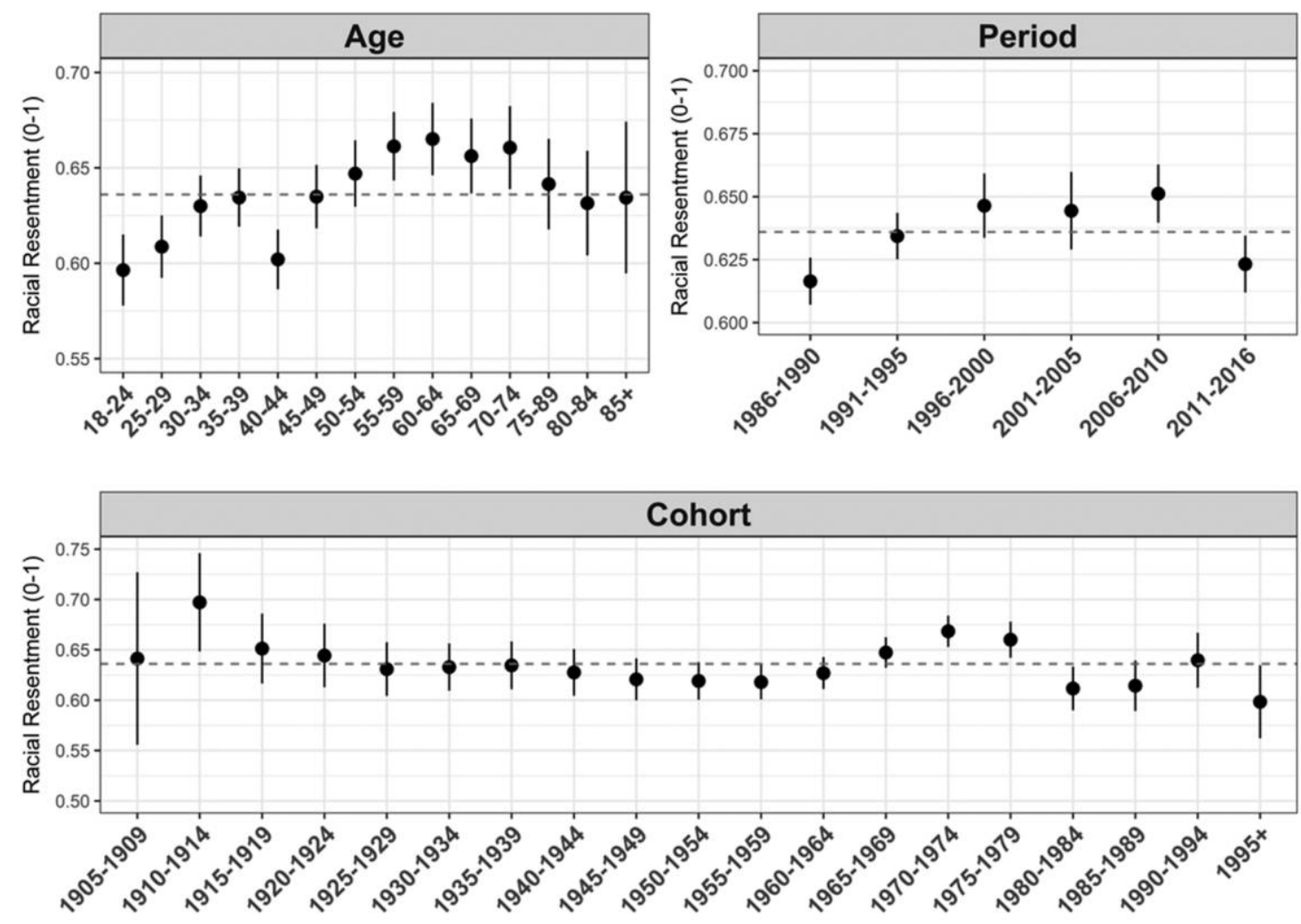

Figure 1. Age-period-cohort model estimates

"old-fashioned" racial stereotypes and other grievances that have been tightly connected to older whites' racial attitudes.

\section{WHEN LESS IS MORE}

Our goal is to assess whether the relationship between racial resentment and millennials' political attitudes and policy preferences is distinctly different from their predecessors' attitudes. As mentioned, we expect that due to the millennials' socialization in a color-blind era, reporting higher levels of racial animus takes greater gall for members of this generation; consequently, we expect that the effect of racial resentment will be much greater and more vicious than it is for older whites.

To test this hypothesis, we employ data from the 2016 ANES. It asks respondents an array of questions that relates to old-fashioned racism, an age-old question focused the extent to which the government should aid blacks, another on perceptions of racial discrimination, and a new question about the Black Lives Matter movement. The 2016 ANES collected data from 3,038 non-Hispanic white respondents. There were 827 millennials, and 2,211 older whites. Across all of the analyses we use the four-question racial resentment battery and, as we did before, scale it to run from 0 (least racially resentful) to 1 (most racially resentful) as our main independent variable.

\section{Old-fashioned racism}

To test whether racial resentment is more closely related with old-fashioned racism for one generation or another, we rely on questions that assess stereotypes. Specifically, for dependent variables, we use the differences between how a respondent placed both whites and blacks on two "oldfashioned" stereotype scales: hardworking/lazy and peaceful/ violent. Each item asked the respondent to place the group on this scale from 1 to 7 , which we rescaled to run from 0 to 6 , where higher values represent a more positive rating (either more hardworking or more peaceful). We then subtract the rating of blacks from the placement of whites to get a difference score. Higher scores indicate a prowhite/antiblack bias. When we regress this variable on the racial resentment scale, the coefficient for racial resentment represents the magnitude of racial stereotyping between the least and most racially resentful respondents.

First, we present two linear regression models first as bivariate regressions, one each for millennials and older whites. ${ }^{9}$ We then present a third model, which includes the

9. We thank one of the anonymous reviewers for this suggestion, as well as their insistence that we replicate the main findings in several larger surveys. Tables A1-A3 (available online) contain several statistical models from other large sample surveys that support our main findings. 
interaction term between a dummy variable indicating a millennial and the racial resentment scale. These models are simple, but they provide a great deal of information, marked by the size of the $R^{2}$ s. The results for each of the old-fashioned stereotype variables are presented in tables 3 and 4.

Tables 3 and 4 show that the effect of racial resentment on these stereotypes is signed in the expected direction; those who are more racially resentful hold more negative stereotypes of blacks when compared to whites. Still, there are important things to note. First, the significant coefficient for the millennial indicator variable indicates that white millennials generally have lower levels of these stereotypes. However, comparing the estimates in the first and second columns, we can see the coefficient for racial resentment is larger in magnitude for millennials than older whites. This provides an initial indication that the effect of racial resentment is different for younger whites.

More importantly, the interaction effect, represented in the third column of tables 3 and 4 provide more evidence that the influence of racial resentment has a greater impact on millennials in comparison to their predecessors. The third column of estimates in table 3 indicates that, among older whites, the estimated difference between the least and most racially resentful person is 2.71 (on a 13-point scale from -6 to 6), meaning that we would expect the most racially resentful person to rate blacks as 2.71 points more violent than the least racially resentful person. The interactive term between the indicator for a millennial respondent and the

Table 3. Racial Resentment and Stereotyping Blacks as Violent

\begin{tabular}{lccc}
\hline & $\begin{array}{c}\text { Older } \\
\text { Whites }\end{array}$ & $\begin{array}{c}\text { Millennial } \\
\text { Whites }\end{array}$ & $\begin{array}{c}\text { Full } \\
\text { Sample }\end{array}$ \\
\hline Racial resentment (RR) & $2.71^{* *}$ & $3.49^{* * *}$ & $2.71^{* * *}$ \\
& $(.12)$ & $(.20)$ & $(.13)$ \\
Millennial & & & $-.42^{* *}$ \\
& & & $(.13)$ \\
RR $\times$ millennial & & & $.79^{* *}$ \\
& & & $(.21)$ \\
Intercept & $-.57^{* *}$ & $-.99^{* *}$ & $-.57^{* *}$ \\
& $(.08)$ & $(.12)$ & $(.08)$ \\
$N$ & 1,856 & 665 & 2,521 \\
Adjusted $R^{2}$ & .225 & .291 & .254 \\
\hline
\end{tabular}

Note. Non-Hispanic whites only, 2016 ANES. Standard errors in parentheses.

$\star p<.05$.

${ }^{* *} p<.01$.

${ }^{* * *} p<.001$.
Table 4. Racial Resentment and Stereotyping Blacks as Lazy

\begin{tabular}{lccc}
\hline & $\begin{array}{c}\text { Older } \\
\text { Whites }\end{array}$ & $\begin{array}{c}\text { Millennial } \\
\text { Whites }\end{array}$ & $\begin{array}{c}\text { Full } \\
\text { Sample }\end{array}$ \\
\hline Racial resentment (RR) & $2.20^{* *}$ & $2.74^{* *}$ & $2.20^{* *}$ \\
& $(.11)$ & $(.20)$ & $(.12)$ \\
Millennial & & & $-.26^{* *}$ \\
& & & $(.12)$ \\
RR $\times$ millennial & & & $.54^{* *}$ \\
& & & $(.21)$ \\
Intercept & $-.41^{* *}$ & $-.67^{* *}$ & $-.41^{* *}$ \\
& $(.07)$ & $(.12)$ & $(.08)$ \\
$N$ & 1,862 & 666 & 2,528 \\
Adjusted $R^{2}$ & .169 & .209 & .186 \\
\hline
\end{tabular}

Note. Non-Hispanic whites only, 2016 ANES. Standard errors in parentheses. ${ }^{*} p<.05$.

${ }^{* *} p<.01$.

${ }^{* * *} p<.001$

racial resentment scale indicates that the difference between the least and most racially resentful millennial is about $30 \%$ larger: $3.50(2.71+0.79)$ points.

A similar result can be shown in the models in table 3, which predicts the old-fashioned stereotype of blacks as lazier than whites using the same simple model specification. Again, the effect for older whites is significantly smaller in magnitude, 2.20, compared to the total effect for millennials (2.74). The results from tables 3 and 4 are shown in figure 2 . As we can see, there is a larger range of stereotype strength for white millennials compared to their predecessors. Among whites who are least racially resentful, millennials do hold more favorable views of blacks compared to their older counterparts. However, at the other end of the graphs, we can see that the most racially resentful millennials hold stronger antiblack stereotypes than older whites. These two analyses show that millennials' racial attitudes are more tightly linked with old-fashioned racist sentiments.

\section{Racialized policy preferences}

What other kinds of way do millennials' racial sentiments differentially effect matters related to racism and racial equality? We examine three additional items: support for governmental aid to blacks, perceptions of "reverse" discrimination, and attitudes toward Black Lives Matter. Again, our modelling strategy stays the same: we estimate the effects of racial resentment and allow for the interactive effect based on generational status. For our first dependent variable, respondents were asked to place themselves on a seven-point scale regarding how much the government should assist 


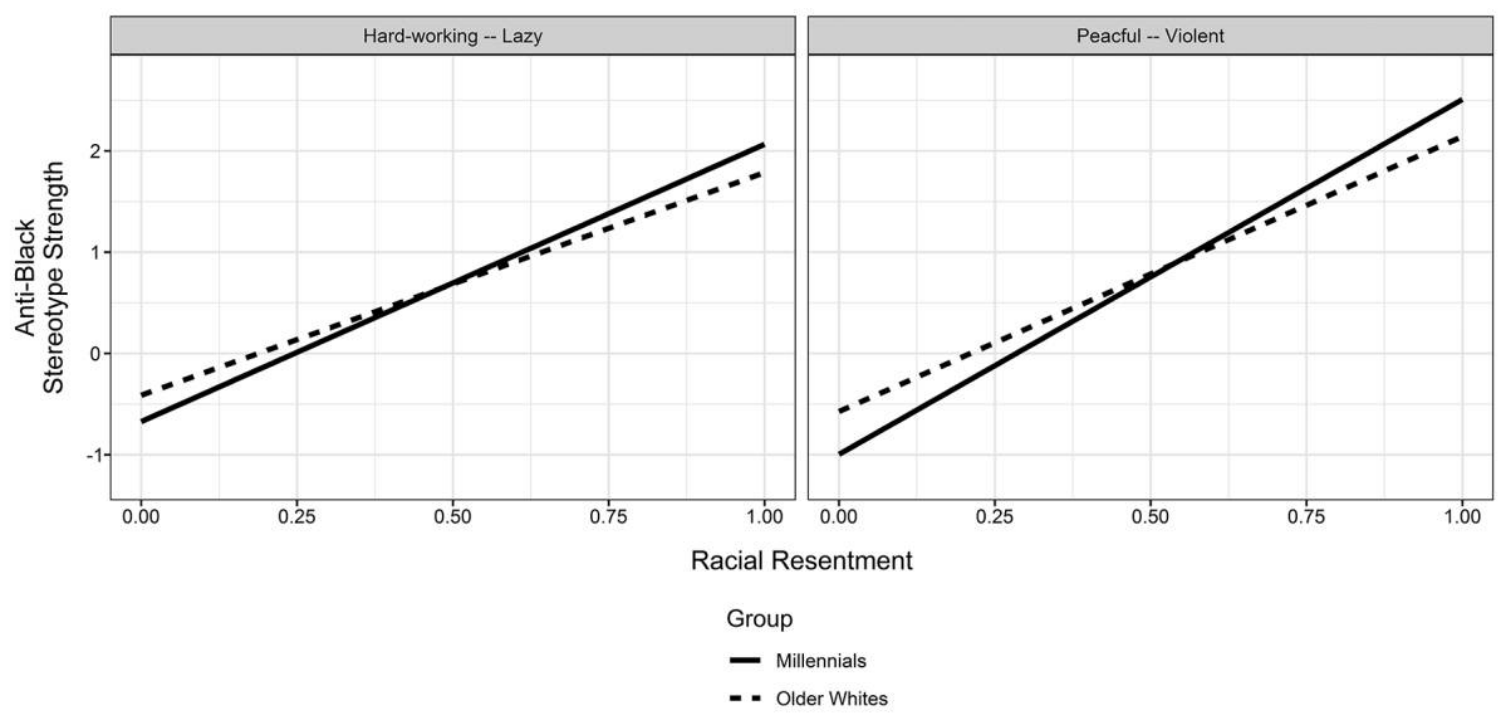

Figure 2. Racial resentment, generational status, and stereotype strength

blacks. We recoded responses to run from 0 (blacks should help themselves) to 6 (government should help blacks).

The second dependent variable was constructed by taking the difference between how much discrimination a respondent said whites face in the United States compared to blacks. Respondents indicated on a five-point scale how much discrimination each group faces from 0 ("none at all") to 4 ("a great deal"). By subtracting the scores, we ascertain how much more or less discrimination the respondent believes that blacks face in comparison to whites. While the percentage of people who believe that whites are discriminated the same amount or more than blacks is $30 \%$, and most of those believe the groups are discriminated against equally, we believe this provides a measure of sentiments around "reverse discrimination," a common rhetorical frame of color-blind racial ideology (Dietrich 2015). Finally, the third column in table 5 examines how racial resentment shapes affective ratings of Black Lives Matter, an organization and social movement that campaigns against systemic racism. This variable is a simple "feeling thermometer" score and ranges from 0 to 100; higher scores indicate greater positive affect.

These results support our second hypothesis: although millennials report lower levels of racial resentment, the effect of racial resentment is such that they hold is more virulent and tightly connected attitudes regarding racial inequity than their predecessors. The findings are consistent and complementary to our previous results on old-fashioned racism: the net difference between the least and most racially resentful whites, on each of these variables, is larger among millennials than it is among older whites. These results are illustrated in figure 3.
The first column of table 5 reveals that not only does racial resentment have a strong correlation with thinking "blacks should help themselves" without any government assistance but also that the effect of racial resentment is significantly larger for millennials. While the least racially resentful millennials do report significantly higher levels of support for governmental aid to blacks than older whites, the most racially resentful millennials are statistically indistinguishable from them. Higher levels of racial resentment are associated

Table 5. Racial Resentment, Generational Status, and Attitudes toward Racialized Targets

\begin{tabular}{lccc}
\hline & & & \\
& Aid to & Levels of \\
& Blacks & $\begin{array}{c}\text { Black } \\
\text { Discrimination }\end{array}$ & $\begin{array}{c}\text { Mives } \\
\text { Matter }\end{array}$ \\
\hline & & & \\
Racial resentment (RR) & $-3.99^{* * *}$ & $2.53^{* * *}$ & $-64.90^{* * *}$ \\
& $(.12)$ & $(.11)$ & $(2.12)$ \\
Millennial & $.58^{* * *}$ & $-.29^{*}$ & 1.19 \\
& $(.13)$ & $(.11)$ & $(2.25)$ \\
RR $\times$ millennial & $-.66^{* * *}$ & $.52^{* *}$ & $-8.49^{*}$ \\
& $(.20)$ & $(.18)$ & $(3.59)$ \\
Intercept & $4.51^{* * *}$ & $-2.69^{* * *}$ & $80.86^{* * *}$ \\
& $(.08)$ & $(.07)$ & $(1.40)$ \\
$N$ & 2,302 & 2,471 & 2,530 \\
Adjusted $R^{2}$ & .459 & .289 & .378 \\
\hline
\end{tabular}

Note. Non-Hispanic whites only, 2016 ANES. Standard errors in parentheses. $* p<.05$.

${ }^{* *} p<.01$.

${ }^{* * *} p<.001$ 


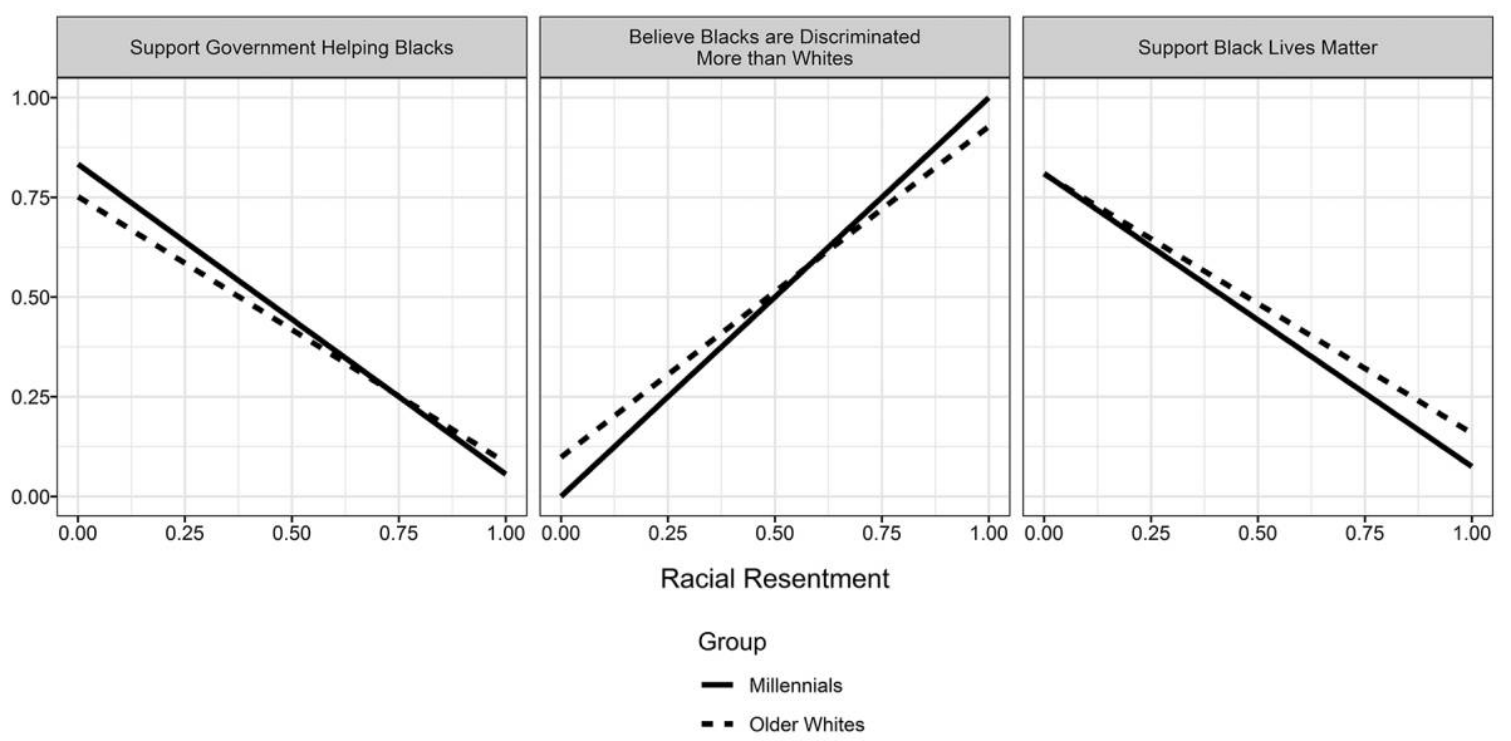

Figure 3. Racial resentment, generational status, and attitudes toward racialized targets

with a respondent perceiving little difference in the levels of systemic discrimination faced by blacks and whites in the United States. Again, while the most racially liberal millennials acknowledge that blacks face higher levels of discrimination, this generational difference is washed out among those who are the most racially resentful.

The last column of table 5 assesses attitudes toward the Black Lives Matter movement, a black social movement that came to fruition around 2014, largely ignited by a slew of fatalities of (unarmed) black people by the police (Taylor 2016) On their face, our findings seem to be ironic. While white millennials, on average, seem to be more liberal on other racial matters, they are no warmer toward a movement that aims to reduce antiblack racism than older whites. The estimated feeling thermometer score for the least racially resentful older whites is about 81 degrees, while the most racially resentful older whites would be estimated to rate Black Lives Matter at just under 16 degrees. Racial resentment has a greater effect for millennials, moving the range from 82 degrees to seven degrees cooler than the most resentful older white Americans-nine degrees.

\section{DISCUSSION}

The debate around racial resentment-as a measure and theory of racial attitudes - has largely been concerned with the extent to which the scale actually measures a "new" form of racial animus or something else altogether (Carmines et al. 2011). But this article departs from that debate by asking a new set of questions that force us to consider the crossgenerational validity of the measure. While there is a great deal of evidence that suggests that the racial resentment battery is indeed a coherent belief system that is different from old fashioned racism and predicts white Americans' attitudes across a range of policy domains, our results suggest that the nature of these attitudes may be shifting. We believe that this shift is caused by intergenerational heterogeneity, from a new cohort of Americans who have been socialized in a very different era than those whose attitudes this measure was originally meant to capture. Younger Americans are socialized in an era marked by color-blind racial ideology. Our findings illustrate the implications of this kind of socialization by revealing that the nature of young whites' racial attitudes is more strongly linked to oldfashioned prejudice than older whites'. In many ways, our findings substantiate Blinder's (2007) “two-tracked socialization" model as well as well as highlights the fifth element that makes up that makes up a color-blind racial structure: "the rearticulation of a number of racial practices characteristic of the Jim Crow period of race relations" (BonillaSilva and Lewis 1999, 56).

Specifically, through the age-period-cohort analysis, we showed that aggregate racial resentment increases over both ages and periods, but decreases in newer cohorts, as many have expected. But we also showed in our second set of analyses, using data from the 2016 ANES, that racial resentment among younger whites may be increasingly related to old-fashioned racial stereotypes and produces more noxious orientations toward racial equity. As we argue above, we believe this can be attributed to two separate phenomena, one historical and one psychosocial. In terms of shared life experiences, we contend that younger people likely have a different set of ideas and references that come to mind when 
they are asked the questions in the racial resentment scale. Second, they have a different set of social norms about what is acceptable to talk about as far as issues of race are concerned. As a result, it might take a higher level of latent prejudice for a millennial to give a "prejudiced" response to a survey question.

These findings raise a series of questions that are outside the scope of a single article. First, major demographic, economic, political, and social changes led scholars like David Sears and Donald Kinder to develop new measures of racial attitudes. Along those same lines, we implore scholars to consider the fact that the structure of attitudes may be changing. At the time the racial resentment scale was developed, the questions presented were read and understood as a subtler way of tapping racial animus than the traditional biological racism or social distance questions. Today we are in a new era of racial politics, where the language of racial attitudes has a different structure from the one developed during the immediate post-Civil Rights era. Our survey questions may wish to better reflect that shift. Psychologists and sociologists have already begun building foundation to measure "color-blind" racial attitudes (Bonilla-Silva 2014; Neville et al. 2000), as well as racial attitudes that may arise as whites become more cognizant of their racial identity due to do the vast demographic changes that have occurred over the past three decades and are projected to occur henceforth (Spanierman and Heppner 2004; Spanierman et al. 2006). We contend that because we have seen another set of significant changes, it is now time to embark on another conceptual enterprise to develop more sensitive measures of racial attitudes; we have done this elsewhere (DeSante and Smith 2017, 2020).

As the title of our article indicates, when it comes to younger whites' racial prejudice, "less is more." While newer cohorts and younger whites seem to exhibit lower levels of racial resentment, the presence of racial animus has a stronger marginal effect on both their old-fashioned racial prejudice, as well as their policy opinions when compared to past generations. Overall, our key findings should serve to reopen the discussions of whether racial progress is inevitable, and if it is not, how should political scientists best measure ever-evolving racial attitudes in a post-Obama America.

\section{ACKNOWLEDGMENTS}

The authors would like to thank Jennifer Merolla, for her incredible patience in helping get this article into press; the anonymous reviewers who repeatedly pushed us to replicate the findings in new data that were made available between the original submission date and the final submis- sion; and Lynn Vavreck and Michael Tesler for sharing the Cooperative Campaign Analysis Project data with us for the analyses in the appendix.

\section{REFERENCES}

Apfelbaum, Evan P., Kristin Pauker, Nalini Ambady, Samuel R. Sommers, and Michael I. Norton. 2008. "Learning (not) to Talk about Race: When Older Children Underperform in Social Categorization.” Developmental Psychology 44 (5): 1513-18.

Apfelbaum, Evan P., Samuel R. Sommers, and Michael I. Norton. 2008. "Seeing Race and Seeming Racist? Evaluating Strategic Colorblindness in Social Interaction." Iournal of Personality and Social Psychology 95 (4): 918-32.

Blinder, Scott B. 2007. "Dissonance Persists Reproduction of Racial Attitudes among Post-Civil Rights Cohorts of White Americans." American Politics Research 35 (3): 299-335.

Bobo, Lawrence. 2000. "Race and Beliefs about Affirmative Action: Assessing the Effects of Interests, Group Threat, Ideology, and Racism." In David O. Sears, Jim Sidanius, and Lawrence Bobo, eds., Racialized Politics: The Debate about Racism in America. Chicago: University of Chicago Press.

Bobo, Lawrence, James R. Kluegel, and Ryan A. Smith. 1997. "Laissez-faire Racism: The Crystallization of a Kinder, Gentler, Antiblack Ideology.” In Steven A. Tuch and Jack K. Martin, eds., Racial Attitudes in the 1990s: Continuity and Change. Westport, CT: Praeger, 16-42.

Bonilla-Silva, Eduardo. 1997. "Rethinking Racism: Toward a Structural Interpretation." American Sociological Review 62 (3): 465-80.

Bonilla-Silva, Eduardo. 2014. Racism without Racists: Color-Blind Racism and the Persistence of Racial Inequality in the United States. 4th ed. Lanham, MD: Rowman \& Littlefield.

Bonilla-Silva, Eduardo. 2017. Racism without Racists: Color-Blind Racism and Racial Inequality in Contemporary America. 5th ed. Lanham, MD: Rowman \& Littlefield.

Bonilla-Silva, Eduardo, and Amanda E. Lewis. 1999. "The New Racism: Racial Structure in the United States, 1960s-1990s.” In Paul Wong, ed., Race, Ethnicity, and Nationality in the USA: Toward the Twenty-First Century. Boulder, CO: Westview, 55-101.

Bonilla-Silva, Eduardo, Amanda Lewis, and David G. Embrick. 2004. “'I Did Not Get That Job because of a Black Man': The Story Lines and Testimonies of Color-Blind Racism.” Sociological Forum 19 (4): 555-81.

Carmines, Edward G., Paul M. Sniderman, and Beth C. Easter. 2011. "On the Meaning, Measurement, and Implications of Racial Resentment." ANNALS of the American Academy of Political and Social Science 634:98-116.

Carr, Leslie G. 1997. “Color-Blind” Racism. Thousand Oaks, CA: Sage.

DeSante, Christopher D. 2013. "Working Twice as Hard to Get Half as Far: Race, Work Ethic, and America's Deserving Poor." American Lournal of Political Science 57 (2): 342-56.

DeSante, Christopher D., and Candis Watts Smith. 2017. "Fear, Institutionalized Racism, and Empathy: The Underlying Dimensions of Whites' Racial Attitudes." Chicago: Midwest Political Science Association.

DeSante, Christopher D., and Candis Watts Smith. 2020. Racial Stasis: The Millennial Generation and Stagnation of Racial Attitudes in American Politics. Chicago: University of Chicago Press.

Dietrich, David R. 2015. "Racially Charged Cookies and White Scholarships: Anti-Affirmative Action Protests on American College Campuses." Sociological Focus 48 (2): 105-25.

Dillon, Sam. 2011. “Students' Knowledge of Civil Rights History Has Deteriorated, Study Finds.” New York Times, September 28. 
Dovidio, John R. 2001. "On the Nature of Contemporary Prejudice: The Third Wave." Lournal of Social Issues 57 (4): 829-49.

Dowden, Sue, and John P. Robinson. 1993. "Age and Cohort Differences in American Racial Attitudes: The Generational Replacement Hypothesis Revisited." In Paul M. Sniderman, Philip E. Tetlock, and Edward G. Carmines, eds., Prejudice, Politics and the American Dilemma. Stanford, CA: Stanford University Press.

Forman, Tyrone. 2006. "Color-Blind Racism and Racial Indifference: The Role of Racial Apathy in Facilitating Enduring Inequalities." In Maria Krysan and Amanda E. Lewis, eds., The Changing Terrain of Race and Ethnicity. New York: Russell Sage.

Frankenberg, Ruth. 1993. White Women, Race Matters: The Social Construction of Whiteness. Minneapolis: University of Minnesota Press.

Hagerman, Margaret A. 2018. White Kids: Growing Up with Privilege in a Racially Divided America. New York: New York University Press.

Henry, P. J., and David O. Sears. 2002. "The Symbolic Racism 2000 Scale." Political Psychology 23 (2): 253-83.

Hochschild, Jennifer, Vesla Weaver, and Traci Burch. 2012. Creating a New Racial Order: How Immigration, Multiracialism, Genomics, and the Young Can Remake Race in America. Princeton, NJ: Princeton University Press.

Hunt, Matthew O. 2007. "African American, Hispanic, and White Beliefs about Black/White Inequality, 1977-2004.” American Sociological Review 72 (3): 390-415.

Jackson, John L., Jr. 2008. Racial Paranoia: The Unintended Consequences of Political Correctness. New York: Basic Civitas.

Kinder, Donald R., and Tali Mendelberg. 2000. "Individualism Reconsidered: Principles and Prejudice in Contemporary American Opinion." In David O. Sears, James Sidanius, and Lawrence Bobo, eds., Racialized Politics: The Debate about Racism in America. Chicago: University of Chicago Press, 44-74.

Kinder, Donald R., and Lynn M. Sanders. 1996. Divided by Color: Racial Politics and Democratic Ideals. Chicago: University of Chicago Press.

Kinder, Donald R., and David O. Sears. 1981. "Prejudice and Politics: Symbolic Racism versus Racial Threats to the Good Life." Lournal of Personality and Social Psychology 40 (3): 414-31.

Kluegel, James R. 1990. "Trends in Whites' Explanations of the BlackWhite Gap in Socioeconomic Status, 1977-1989." American Sociological Review 55 (4): 512-25.

Kluegel, James R., and Lawrence Bobo. 1993. "Dimensions of Whites' Beliefs about the Black-White Socioeconomic Gap." In Paul M. Sniderman, Philip E. Tetlock, and Edward G. Carmines, eds., Prejudice, Politics, and the American Dilemma. Stanford, CA: Stanford University Press.

Lewis, Amanda E. 2001. "There Is No 'Race' in the Schoolyard: ColorBlind Ideology in an (almost) All-White School." American Educational Research Journal 38 (4): 781-811.

Lewis-Beck, Michael S., Charles Tien, and Richard Nadeau. 2010. “Obama’s Missed Landslide: A Racial Cost?" PS: Political Science and Politics 43 (1): 69-76.

Mannheim, Karl. 1952. "The Problem of Generations.” In Karl Mannheim and Paul Kecskemeti, eds., Essays on the Sociology of Knowledge. New York: Oxford University Press, 276-320.

McConohay, John B. 1986. "Modern Racism, Ambivalence, and the Modern Racism Scale." In John R. Dovidio and Samuel L. Gaertner, eds., Prejudice, Discrimination, and Racism. New York: Academic Press, 91-126.

Mueller, Jennifer C. 2017. "Producing Color-Blindness: Everyday Mechanisms of White Ignorance." Social Problems 64 (2): 219-38.

Neundorf, Anja, and Richard G. Niemi. 2014. "Beyond Political Socialization: New Approaches to Age, Period, Cohort Analysis." Electoral Studies 33:1-6
Neville, Helen A., Roderick L. Lilly, Georgia Durham, Richard M. Lee, and LaVonne Browne. 2000. "Construction and Initial Validation of the Color-Blind Racial Attitudes Scale (CoBRAS).” Lournal of Counseling Psychology 47 (1): 59-70.

Page, Susan, and Jenny Ung. 2016. "Poll Shows That Millennials Would Flock to Clinton against Trump." USA Today, March 14.

Pettigrew, Thomas F., and Roel W. Meertens. 1995. "Subtle and Blatant Prejudice in Western Europe." European Journal of Social Psychology 25 (1): 57-75.

Pew Research Center. 2010. "Millennials: Confident, Connected, Open to Change." Pew Research Center, Washington, DC.

Piston, Spencer. 2010. "How Explicit Racial Prejudice Hurt Obama in the 2008 Election." Political Behavior 32 (4): 431-51.

Ries, Brian. 2014. "South Carolina Exit Poll Asks If Blacks Are 'Too Demanding in Their Push for Equal Rights.'” Mashable, November 6. https://mashable.com/2014/11/06/south-carolina-racist-exit-poll/.

Rutten, Tim. 2008. "The Good Generation Gap." Los Angeles Times, February 6. https://articles.latimes.com/2008/feb/06/opinion/oe-rutten6.

Schuman, Howard, Charlotte Steeh, Lawrence Bobo, and Maria Krysan. 1997. Racial Attitudes in America: Trends and Interpretation. Rev. ed. Cambridge, MA: Harvard University Press.

Schwadel, Philip, and Michael Stout. 2012. "Age, Period and Cohort Effects on Social Capital." Social Forces 9 (1): 233-52.

Sears, David O. 1988. "Symbolic Racism." In Phyllis A. Katz and Dalmas A. Taylor, eds., Eliminating Racism: Profiles in Controversy. New York: Plenum, 53-84.

Sears, David O. 1993. "Symbolic Politics: A Socio-Psychological Theory." In Shanto Iyengar and William J. McGuire, eds., Explorations in Political Psychology. Durham, NC: Duke University Press, 11349.

Sears, David O., John J. Hetts, Jim Sidanius, and Lawrence Bobo. 2000. "Race in American Politics: Framing the Debates." In David O. Sears, Jim Sidanius, and Lawrence Bobo, eds., Racialized Politics: The Debate about Racism in America. Chicago: University of Chicago Press.

Sears, David O., Jim Sidanius, and Lawrence Bobo. 2000. Racialized Politics: The Debate about Racism in America. Chicago: University of Chicago Press.

Smith, Candis Watts. 2014. "Shifting from Structural to Individual Attributions of Black Disadvantage: Age, Period, and Cohort Effects on Black Explanations of Racial Disparities." Iournal of Black Studies 45 (5): 432-52.

Sniderman, Paul M., Gretchen C. Crosby, and William G. Howell. 2000. “The Politics of Race." In David O. Sears, Jim Sidanius, and Lawrence Bobo, eds., Racialized Politics: The Debate about Racism in America. Chicago: University of Chicago Press.

Sniderman, Paul M., and Thomas Leonard Piazza. 1993. The Scar of Race. Cambridge, MA: Belknap Press of Harvard University Press.

Sniderman, Paul M., and Philip E. Tetlock. 1986. "Symbolic Racism: Problems of Motive Attribution in Political Analysis." Journal of Social Issues 42 (2): 129-50.

Spanierman, Lisa B., and Mary J. Heppner. 2004. "Psychosocial Costs of Racism to Whites Scale (PCRW): Construction and Initial Validation." Journal of Counseling Psychology 51 (2): 249-62.

Spanierman, Lisa B., V. Paul Poteat, Amanda M. Beer, and Patrick Ian Armstrong. 2006. "Psychosocial Costs of Racism to Whites: Exploring Patterns through Cluster Analysis." [ournal of Counseling Psychology 53 (4): 434-41.

Steeh, Charlotte, and Howard Schuman. 1992. "Young White Adults: Did Racial Attitudes Change in the 1980s?" American Journal of Sociology 98 (2): 340-67. 
Stegmueller, Daniel. 2014. "Bayesian Hierarchical Age-Period-Cohort Models with Time-Structured Effects: An Application to Religious Voting in the US, 1972-2008." Electoral Studies 33:52-62.

Stoker, Laura. 1998. "Understanding Whites' Resistance to Affirmative Action: The Role of Principled Commitments and Racial Prejudice.” In Jon Hurwitz and Mark Peffley, eds., Perception and Prejudice: Race and Politics in the United States. New Haven, CT: Yale University Press.

Taylor, Keeanga-Yamahtta. 2016. From \#BlackLivesMatter to Black Liberation. Chicago: Haymarket.

Tesler, Michael. 2012. “The Spillover of Racialization into Health Care: How President Obama Polarized Public Opinion by Racial Attitudes and Race." American Journal of Political Science 56 (3): 690-704.

Tesler, Michael. 2013. "The Return of Old-Fashioned Racism to White Americans' Partisan Preferences in the Early Obama Era." Journal of Politics 75 (1): 110-23.

Tesler, Michael. 2016. Post-Racial or Most-Racial? Race and Politics in the Obama Era. Chicago: University of Chicago Press.

Tesler, Michael, and David O. Sears. 2010. Obama's Race: The 2008 Election and the Dream of a Post-racial America. Chicago: University of Chicago Press.
Unnever, James D., and Francis T. Cullen. 2007. "The Racial Divide in Support for the Death Penalty: Does White Racism Matter?" Social Forces 85 (3): 1281-301.

Valentino, Nicholas A., and Ted Brader. 2011. “The Sword's Other Edge: Perceptions of Discrimination and Racial Policy Opinion after Obama." Public Opinion Quarterly 75 (2): 201-26.

Wilson, David C., and Darren W. Davis. 2011. "Reexamining Racial Resentment: Conceptualization and Content." Annals of the American Academy of Political and Social Sciences 634:117-33.

Yang, Yang, Wenjiang J. Fu, and Kenneth C. Land. 2004. "A Methodological Comparison of Age-Period-Cohort Models: The Intrinsic Estimator and Conventional Generalized Linear Models." Sociological Methodology 34 (1): 75-110.

Yang, Yang, and Kenneth C. Land. 2013. Age-Period-Cohort Analysis: New Models, Methods, and Empirical Applications. Boca Raton, FL: Chapman \& Hall.

Yang, Yang, Sam Schulhofer-Wohl, Wenjiang J. Fu, and Kenneth C. Land. 2008. "The Intrinsic Estimator for Age-Period-Cohort Analysis: What It Is and How to Use It." American Journal of Sociology 113 (6): 1697736. 